\title{
Effects of Different Zn Supply Levels on Physiological Parameters, Seed Zn Concentration and Root Cell Ultrastructure in three Different Genotypes of Brassica Species
}

\author{
Xinbin Zhou, Weihong Xu*, Zhengyin Wang and Deti Xie \\ College of Resources and Environmental Sciences, Southwest University, Chongqing 400715, People's Republic of China \\ *For correspondence: xuwei_hong@163.com
}

\begin{abstract}
Crop $\mathrm{Zn}$ content is different between various crop species. The purpose of the present study was to determine $\mathrm{Zn}$ response in seed of three species of Brassica (B. napus, B. juncea and B. campestris) when exposed to different Zn supply levels ( 0 , 1,5 , 10 and $20 \mathrm{mg} \mathrm{kg}^{-1}$ ) in pot experiment. The results showed that the activities of antioxidant enzymes, net photosynthetic rate $\left(\mathrm{P}_{\mathrm{n}}\right)$, stomatal conductance $\left(\mathrm{G}_{\mathrm{s}}\right)$, transpiration rate $\left(\mathrm{T}_{\mathrm{r}}\right)$ in leaf, and dry weights of plant, straw, leaf and seed increased at

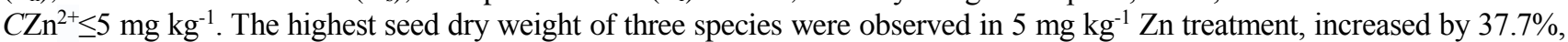
$82.6 \%$ and $18.0 \%$ compared to the controls, respectively. The ultrastructural damage was found in the root tip cells for $B$. napus and YR in the presence of $20 \mathrm{mg} \mathrm{kg}^{-1} \mathrm{Zn}$, while intact structure of the root tip cells was observed in $B$. campestris. The total amino acid content of root exudates in $B$. juncea and B. napus was significantly higher than that of $B$. campestris in the presence of 1 and $20 \mathrm{mg} \mathrm{kg}^{-1} \mathrm{Zn}$. High supply level of $\mathrm{Zn}^{2+}\left(20 \mathrm{mg} \mathrm{kg}^{-1}\right)$ could promote the secretion of amino acids in root exudates. Dry weight (stem, leaf and seed) of B. napus reveal a decreasing trend when Zn supplied at levels above $10 \mathrm{mg} \mathrm{kg}^{-1}$. As the increase of $\mathrm{Zn}$ supply level, the concentrations of $\mathrm{Zn}$ in seed of rape revealed an increasing trend. The best $\mathrm{Zn}$ supply level for having more biomass and more $\mathrm{Zn}$ in seeds of rape without toxic effects was observed at $10 \mathrm{mg} \mathrm{kg}^{-1}$. The highest of $\mathrm{Zn}$ concentration in seed were observed in B. napus may be due to due to more root exudates. Zinc concentration in $\mathrm{Zn}$-highefficiency species is related to the absorption capacity of the plant's roots and the ability to change soil Zn availability (C) 2017 Friends Science Publishers
\end{abstract}

Keywords: Seed Zn concentration; Physiological characteristics; Root exudates; Rape species; Ultrastructure of root cell

\section{Introduction}

Zinc $(\mathrm{Zn})$ is an essential nutrient in plants, animals and humans, and plays a fundamental role in several critical functions in protein metabolism, gene expression, structural and functional integrity of biomembranes and photosynthetic carbon metabolism of plant as a cofactor for more than 300 enzymes in the human body (Poblaciones and Rengel, 2016). In humans, $\mathrm{Zn}$ deficiency is associated with severe health complications, including impairments of physical growth, learning ability an immune system, and increased risk of infections, DNA damage and cancer development (Levenson and Morris, 2011). However, more than $30 \%$ of the world's population is $\mathrm{Zn}$ deficient, with $\mathrm{Zn}$ deficiency being the $11^{\text {th }}$ most important factor causing disease or death in the world, and the $5^{\text {th }}$ most important factor in developing countries (WHO, 2011). In China, nutrition and food hygiene data reported by Academy of Preventive Medicine Institute show that zinc daily intakes of $60 \%$ of China children are less than half of WHO recommended amount, due to seventy-five percent energy of Chinese come from rice, wheat and corn, whose zinc concentrations are only 10-30 $\mathrm{mg} \mathrm{kg}^{-1}$ (Jiang et al., 2009).

Food consumption provides the principal route of $\mathrm{Zn}$ supply in most human populations. A diet consisting of a high proportion of cereal-based food with low $\mathrm{Zn}$ contents is considered one of the major reasons for the widespread occurrence of $\mathrm{Zn}$ deficiency in humans, especially in developing countries (Alloway, 2008). In Zn-deficient conditions, agronomic biofortification has proved to be an effective and fast solution to increasing $\mathrm{Zn}$ concentration in the edible parts of several crops (Ghasemi et al., 2013; Gomez-Coronado et al., 2015). Biofortification via $\mathrm{Zn}$ application has been confirmed to be effective in increasing $\mathrm{Zn}$ concentration in crops grown in either Zn-sufficient or Zn-deficient soils (Poblaciones and Rengel, 2016).

Zinc content in grain or seed is different between species and species of plant, and soil types (Dong et al., 1995; Erenoglu et al., 2001; Coolong and Randle, 2003; Wang and Jin, 2005). Brassica (Brassica campestris, Brassica napu and Brassica juncea) is one of the four main oil crops in China (including rape, soybean, peanut and

To cite this paper: Zhou, X., W. Xu, Z. Wang and D. Xie, 2017. Effects of different Zn supply levels on physiological parameters, seed Zn concentration and root cell ultrastructure in three different genotypes of Brassica species. Int. J. Agric. Biol., 19: 282-290 
sesame), and the main edible plant oil for Chinese. But little investigation was reported about the physiological mechanisms of different seed $\mathrm{Zn}$ concentration in different species of Brassica. The purpose of this study was to determine $\mathrm{Zn}$ response and $\mathrm{Zn}$ accumulation in seed of three species (Brassica campestris, Brassica napus and Brassica juncea) when exposed to different $\mathrm{Zn}$ supply levels. Understanding the range of genotypic variation in seed $\mathrm{Zn}$ accumulation and response to $\mathrm{Zn}$ will provide a basis for micronutrient studies.

\section{Materials and Methods}

\section{Plant Material, Soil and Heavy Metal Treatments}

Brassica campestris (Nantong, Jiangsu, China), Brassica napus (H33, France) and Brassica juncea (Luoping, Yunnan, China) seeds were provided by the Oil Crops Research Institute (OCRI) of the Chinese Academy of Agricultural Sciences (CAAS). The soil collected from the town of Jiulongpo, Chongqing, China, was characterized as having a $\mathrm{pH}$ of 6.9 (soil: water $=1: 2.5$ ), an organic matter and total $\mathrm{N}$ content of 33.3 and $1.21 \mathrm{~g} \mathrm{~kg}^{-1}$. Available N, P, $\mathrm{K}$ and $\mathrm{Zn}$ were 110.8, 10.6, 104.6 and $1.9 \mathrm{mg} \mathrm{kg}{ }^{-1}$, respectively. Soil cation exchange capacity (CEC) was 207 mmol kg-1.

The pot experiment was conducted with $\mathrm{Zn}$ supply levels of 0 (the control), 1, 5, 10 and $20 \mathrm{mg} \mathrm{kg}$ $\left(\mathrm{ZnSO}_{4} \cdot 7 \mathrm{H}_{2} \mathrm{O}\right)$. Soil $(5.0 \mathrm{~kg})$ was mixed with the designated amounts of $\mathrm{Zn}$ and fertilizers containing $150 \mathrm{mg} \mathrm{kg}^{-1} \mathrm{~N}$ as urea, $100 \mathrm{mg} \mathrm{kg}^{-1} \mathrm{P}$ as $\mathrm{KH}_{2} \mathrm{PO}_{4}$ and $150 \mathrm{mg} \mathrm{kg}^{-1} \mathrm{~K}$ as KCl. A root-bag technique was used to separate the rhizosphere from bulk soil. The root-bags $(12 \mathrm{~cm}$ in depth and $16 \mathrm{~cm}$ in diameter) made of 500-mesh nylon screen, were filled with $200 \mathrm{~g}$ soil as rhizosphere, and then buried in the centre of a plastic pot (30 cm in depth, $28 \mathrm{~cm}$ in diameter) containing $4.90 \mathrm{~kg}$ bulk soil (Xu et al., 2007).

Two uniform seedlings $(3 \mathrm{~cm}$ in root length, $10 \mathrm{~cm}$ in seedling height) were transplanted into the root-bag of each pot under growth chamber conditions at a day/night cycle: $16 \mathrm{~h}, 30 \pm 2^{\circ} \mathrm{C} / 8 \mathrm{~h}, 25 \pm 2^{\circ} \mathrm{C}$ and $75 \%$ relative humidity. The experimental design was completely randomized, and each treatment was replicated four times. Distilled water was added daily to maintain soil moisture to field capacity level. After 90 days.

The youngest and the second youngest fully opened leaves of one pot of each treatment were cut for analysis of photosynthesis and activities of antioxidant enzymes. A replication was used for the determination of root tip cell ultrastructure and characteristics of root exudates. All remaining plants were harvested at maturity, and washed thoroughly with distilled water, separated into roots, shoots and seeds, oven-dried at $65^{\circ} \mathrm{C}$ for $72 \mathrm{~h}$. Dry weights of roots, shoots and seeds were recorded. The concentrations of $\mathrm{Zn}$ in straw, roots and seeds were determined.

\section{Analyses of Enzyme, Proline and Malondialdehyde}

The activity of catalase (CAT) was measured using a microtiter plate assay (Hansen et al., 2006). The activity of peroxidase (POD) was determined according to Nakano and Asada (1981). The activity of superoxide dismutase (SOD) was determined by the method of Minami and Yoshikawa (1979). Proline was extracted and determined by the method of Bates et al. (1973). The MDA assay was determined by the method of Bird et al. (1983).

\section{Photosynthesis Characteristics Analyses}

Gas exchange was measured between 10.00 and 12.00 local time. Measurements of net photosynthetic rate $\left(\mathrm{P}_{\mathrm{N}}\right)$, transpiration rate $\left(\mathrm{T}_{\mathrm{r}}\right)$, stomatal conductance $(\mathrm{Gs})$ and $\mathrm{CO}_{2}$ concentration $\left(\mathrm{C}_{\mathrm{i}}\right)$ were carried out with LiCor-6400 Photosynthetic gas analysis system (Licor Inc. Lincoln, Nebraska, USA).

\section{Collection and Analyses of Root Exudates}

After ninety days of cultivation, the whole root systems of intact plants were removed gently from root-bags. To collect the root exudates, all plants were placed into sterile $500 \mathrm{~mL}$ glass container covered with aluminum foil paper to avoid contamination and light of sterile aerated de-ionized water. Each rape was cultured in triplicate and each repetition contained 2 rape seedlings. Plants were maintained in a biochemical incubator at $30^{\circ} \mathrm{C}$ for $24 \mathrm{~h}$ to collect root exudates. The collected root exudates were filtered by a double layer of Whatman no. 1 filter paper, and immediately frozen at $-30^{\circ} \mathrm{C}$, freeze-dried, and weighed. The lyophilized powder of root exudates was dissolved in deionized water to make concentrated extracts $1 \mathrm{~g} \cdot \mathrm{L}^{-1}$ for the bioassay and the analysis of the composition of organic components. The LMW organic acids were measured by a GBC-HPLC instrument (LC-1140 system organiser, LC-1150 pump, LC1206 multiwave-length UV/VIS detector) using reversephase BST Nucleosil C-18 $(250 \times 4 \mathrm{~mm}, 5 \mu \mathrm{m}$ particle size $)$ column and a BST Nucleosil C-18 $(30 \times 4 \mathrm{~mm}, 5 \mu \mathrm{m}$ particle size) guard column. Column effluents were monitored at $210 \mathrm{~nm}$ at a flow rate of $0.5 \mathrm{~mL} \mathrm{~min}^{-1}$. The mobile phase was a buffer solution containing $0.01 \mathrm{M} \mathrm{KH}_{2} \mathrm{PO}_{4}$ adjusted to pH 2.2 with $\mathrm{H}_{3} \mathrm{PO}_{4}$ solution and was filtered using a Nalgene $0.45-\mu \mathrm{m}$ nylon membrane filter. The injection volume was $20 \mu \mathrm{L}$, and each treatment was analyzed in triplicates. A multilevel calibration method with daily prepared standard solutions was used for quantitative determination of the LMW organic acids (Tolrà et al., 1996). The concentrations of amino acids were determined by a PICO-TAG (Water Ltd, USA).

\section{Analyses of Root Tip Cell Ultrastructure}

For electron-microscopic analyses, five roots per each treatment were fixed in $2 \%$ glutaraldehyde in $0.1 \mathrm{M}$ 
cacodylate buffer $\mathrm{pH} 7.5$ for $2 \mathrm{~h}$ at $4^{\circ} \mathrm{C}$, then rinsed with the same buffer and postfixed in 1\% osmium tetroxide for $2 \mathrm{~h}$. After dehydration in a graded ethanol series, they were embedded in Epon-Spurr's resin mixture. Ultrathin sections, stained with uranyl acetate and lead citrate, were examined in a Jeol 1010 TEM at $80 \mathrm{kV}$ and documentation was made on a photographic film for electron microscopy (Hitachi600, Hitachi Ltd, Japan).

The ultrastructure of meristematic cells of $\mathrm{Zn}$-treated plants was observed and the number of altered mitochondria, Golgi apparatus and vacuoles (expressed as the percentage of the total number of those organelles at the analyzed microphotographs) as well the frequency of circular ER and multivesicular bodies (expressed as the percentage of the analyzed cell profiles, in which those structures occurred) were determined on at least 100 micrographs (20 per root) from each series (Glińska and Gabara, 2000).

\section{Analyses of Plant Zn Concentration and Soil Physico- chemical Properties}

Dried plant samples were ground and digested with concentrated $\mathrm{HNO}_{3}-\mathrm{HClO}_{4}$. Available $\mathrm{Zn}$ was extracted with diethylene-triaminepentaacetic acid (DTPA). Zinc concentrations in the solution were analyzed using a flame atomic absorption spectrometer (AAC) (Perkin Elmer SIMMA 6000, Norwalk, CT) (Sharma et al., 2004). For quality assurance, the National Institute of Standards and Technology reference plant materials (GBW \# 08513) and soils (GBW \# 08303) were used to check the efficiency of the digestion/extraction procedures and FAAS measurements. For all plant and soil samples, the recovery rate of $\mathrm{Zn}$ was higher than $95 \%$, and the relative standard deviation (RSD) of the precision was within $10 \%$. Soil $\mathrm{pH}$ (soil: water $=1: 5$ ) was measured with a digital acidometer (pHS-4C, Japan). Cation exchange capacity and extractable $\mathrm{P}$ of soil were determined by the method of Rayment and Higginson (1992). Organic matter content was determined using the modified Walkley and Black method (dichromate oxidation and titration; McCleod, 1975).

\section{Statistical Analysis}

The statistical analysis was performed using the SPSS 21.0 software. The effects of $\mathrm{Zn}$ supply level on accumulation of $\mathrm{Zn}$, and physiological characterization for different rape species were subjected to a two-way analysis of variance (ANOVA i.e., species and Zn supply levels), followed by the least significant difference test $(p=0.05)$.

\section{Results}

\section{Biomass}

Significant differences of dry weights for roots, stems, leaves and seeds were found among three rape species, as well as Zn supply levels (Figs. 1-4). Meanwhile, a significant difference of interaction between $\mathrm{Zn}$ supply level and species was also observed. As the increase of $\mathrm{Zn}$ supply levels, the dry weights of roots, stems, leaves and seeds as well as total dry weight of three rape species firstly increased, and then decreased. The maximum weights of stems, leaves, roots and seeds, as well as total dry weight of B. napus and B. campestris were determined at $\mathrm{Zn}$ supply level of $5.0 \mathrm{mg} \mathrm{kg}^{-1}$, which exhibited the enhancement by $14.3 \%, 75.3 \%, 79.1 \%, 37.7 \%$ and $1.4 \%$ (B. napus), and $14.9 \%, 64.4 \%, 48.1 \%, 18.0 \%$ and $20.5 \%$ (B. campestris) for both rape species compared to the control, respectively. The maximum dry weights of stems, leaves, seeds, as well as total dry weight from $B$. juncea were found at $\mathrm{Zn}$ supply level of $5.0 \mathrm{mg} \mathrm{kg}^{-1}$ with the enhancement by $33.9 \%, 117.2 \%, 82.5 \%$ and $51.5 \%$, respectively except the maximum dry weight of roots from $B$. juncea was determined at $\mathrm{Zn}$ supply level of $20.0 \mathrm{mg} \mathrm{kg}$. . The dry weight (stem, leaf and seed) of rape species reveal a decreasing trend when $\mathrm{Zn}$ supplied at levels above $10.0 \mathrm{mg} \mathrm{kg}^{-1}$. Under the same $\mathrm{Zn}$ supply level, seed dry weight revealed an order as $B$. campestris $>$ B. napus $>$ B. juncea.

\section{Enzyme Activity}

As shown in Table 1, significant differences of SOD, CAT and POD activities in leaf of rape were observed among Zn supply levels and various rape species $(p<0.05)$, and significant interaction were also found between rape species and $\mathrm{Zn}$ supply level $(p<0.05)$. The activities of SOD, CAT and POD in three rape species revealed two major trends as the increase of $\mathrm{Zn}$ supply levels. The first changing trend was the decrease in activities of SOD, CAT and POD in B. napus with the increase of $\mathrm{Zn}$ supply level, and the lowest activities of these enzymes were observed at $\mathrm{Zn}$ supply level of $5.0 \mathrm{mg} \mathrm{kg}^{-1}$; in contrast, as the further increase in $\mathrm{Zn}$ supply level, the activities of these enzymes revealed a gradually increasing trend. However, when Zn supply level was increased up to 20.0 $\mathrm{mg} \mathrm{kg} \mathrm{kg}^{-1}$, the activities of these enzymes exhibited the reduction again. The second changing trend was the increasing activities of SOD, CAT and POD in B. juncea and $B$. campestris with the increase of $\mathrm{Zn}$ supply level. Under the conditions with various $Z n$ supply levels, the activities of SOD, CAT and POD in B. campestris revealed higher level among three rape species.

\section{Proline and Malondialdehyde Contents}

As shown in Table 1, significant difference of transpiration rate (Tr) in leaf was found among rape species and $\mathrm{Zn}$ supply levels $(p<0.05)$. The maximum $\mathrm{Tr}$ in rape species was observed at $\mathrm{Zn}$ supply level of 5.0 $\mathrm{mg} \mathrm{kg}^{-1}$ with the increase by $22.2 \%, 54.2 \%$ and $20.4 \%$ when compared with the control, respectively. $\mathrm{Tr}$ in leaf of 
Effect of Zinc on Root Cell Ultrastructure / Int. J. Agric. Biol., Vol. 19, No. 2, 2017

Table 1: Effects of different $\mathrm{Zn}$ supply levels on enzyme activity proline and malondialdehyde contents in rape

\begin{tabular}{|c|c|c|c|c|c|c|}
\hline Species & $\begin{array}{l}\text { Zn supply levels } \\
\left(\mathrm{mg} \mathrm{kg}^{-1}\right)\end{array}$ & $\begin{array}{l}\text { SOD activity } \\
\left(\mathrm{U} \min ^{-1} \mathrm{~g}^{-1} \mathrm{FW}\right)\end{array}$ & $\begin{array}{l}\text { CAT activity } \\
\left.\text { (U } \min ^{-1} \mathrm{~g}^{-1} \mathrm{FW}\right)\end{array}$ & $\begin{array}{l}\text { POD activity } \\
\left(\mathrm{U} \mathrm{min}^{-1} \mathrm{~g}^{-1} \mathrm{FW}\right)\end{array}$ & $\begin{array}{l}\text { Proline content } \\
\left(\mu \mathrm{g} \mathrm{g}^{-1} \mathrm{FW}\right)\end{array}$ & $\begin{array}{l}\text { malondialdehyde content } \\
\left(\mu \mathrm{mol} \mathrm{g}^{-1} \mathrm{FW}\right)\end{array}$ \\
\hline \multirow[t]{5}{*}{ B. napus } & 0 & $508.65 \pm 17.59 \mathrm{a}$ & $4.33 \pm 0.52 \mathrm{~b}$ & $473.40 \pm 13.53 \mathrm{a}$ & $44.34 \pm 1.67 \mathrm{a}$ & $7.13 \pm 0.64 b$ \\
\hline & 1 & $488.57 \pm 15.11 \mathrm{~b}$ & $4.07 \pm 0.47 \mathrm{c}$ & $430.26 \pm 7.65 b$ & $24.91 \pm 1.21 \mathrm{c}$ & $6.53 \pm 0.51 \mathrm{c}$ \\
\hline & 5 & $445.33 \pm 11.27 \mathrm{c}$ & $3.71 \pm 0.32 \mathrm{~d}$ & $405.89 \pm 10.27 \mathrm{c}$ & $20.37 \pm 0.79 d$ & $5.06 \pm 0.73 \mathrm{~d}$ \\
\hline & 10 & $456.10 \pm 13.64 \mathrm{c}$ & $4.51 \pm 0.51 \mathrm{a}$ & $483.54 \pm 14.63 \mathrm{a}$ & $31.34 \pm 1.11 \mathrm{~b}$ & $6.48 \pm 0.41 \mathrm{c}$ \\
\hline & 20 & $400.50 \pm 9.35 \mathrm{~d}$ & $4.44 \pm 0.44 \mathrm{ab}$ & $319.44 \pm 5.79 \mathrm{~d}$ & $46.82 \pm 1.57 \mathrm{a}$ & $8.48 \pm 0.42 \mathrm{a}$ \\
\hline \multirow[t]{5}{*}{ B. juncea } & 0 & $482.76 \pm 14.23 b$ & $4.21 \pm 0.37 \mathrm{a}$ & $501.90 \pm 14.19 a$ & $30.11 \pm 1.23 \mathrm{a}$ & $6.08 \pm 0.26 \mathrm{~b}$ \\
\hline & 1 & $449.74 \pm 8.11 \mathrm{c}$ & $3.77 \pm 0.29 \mathrm{c}$ & $470.23 \pm 9.09 b$ & $23.87 \pm 0.83 \mathrm{c}$ & $5.17 \pm 0.33 d$ \\
\hline & 5 & $418.91 \pm 6.98 \mathrm{~d}$ & $3.22 \pm 0.25 \mathrm{~d}$ & $341.63 \pm 7.76 \mathrm{~d}$ & $11.26 \pm 0.62 \mathrm{~d}$ & $5.05 \pm 0.21 \mathrm{e}$ \\
\hline & 10 & $465.13 \pm 12.45 b c$ & $4.07 \pm 0.43 b$ & $427.62 \pm 9.53 \mathrm{c}$ & $25.72 \pm 1.24 \mathrm{~b}$ & $5.99 \pm 0.49 \mathrm{c}$ \\
\hline & 20 & $570.50 \pm 19.21 \mathrm{a}$ & $4.22 \pm 0.23 \mathrm{a}$ & $493.55 \pm 12.34 \mathrm{a}$ & $31.28 \pm 1.77 \mathrm{a}$ & $6.50 \pm 0.56 \mathrm{a}$ \\
\hline \multirow[t]{5}{*}{ B. campestris } & 0 & $533.23 \pm 16.72 b$ & $4.47 \pm 0.41 \mathrm{ab}$ & $562.85 \pm 23.65 \mathrm{ab}$ & $73.23 \pm 4.32 \mathrm{~b}$ & $4.86 \pm 0.45 b$ \\
\hline & 1 & $519.11 \pm 15.44 \mathrm{c}$ & $4.16 \pm 0.57 \mathrm{c}$ & $366.77 \pm 6.29 \mathrm{c}$ & $42.22 \pm 2.65 \mathrm{c}$ & $4.74 \pm 0.32 \mathrm{c}$ \\
\hline & 5 & $503.18 \pm 9.54 d$ & $3.97 \pm 0.35 \mathrm{~d}$ & $256.36 \pm 5.43 \mathrm{~d}$ & $23.85 \pm 1.79 \mathrm{e}$ & $4.04 \pm 0.21 \mathrm{~d}$ \\
\hline & 10 & $527.23 \pm 16.47 \mathrm{bc}$ & $4.36 \pm 0.46 \mathrm{~b}$ & $559.98 \pm 21.12 b$ & $37.01 \pm 2.46 \mathrm{~d}$ & $5.58 \pm 0.43 \mathrm{ab}$ \\
\hline & 20 & $557.73 \pm 21.14 \mathrm{a}$ & $4.59 \pm 0.59 \mathrm{a}$ & $572.48 \pm 27.62 \mathrm{a}$ & $81.43 \pm 3.73 \mathrm{a}$ & $5.66 \pm 0.23 \mathrm{a}$ \\
\hline \multicolumn{7}{|l|}{$\operatorname{Probability}(P)$} \\
\hline \multicolumn{2}{|l|}{ Species } & $<0.001$ & $<0.001$ & $<0.001$ & $<0.001$ & $<0.001$ \\
\hline \multicolumn{2}{|c|}{$\mathrm{Zn}$ levels } & $<0.001$ & $<0.001$ & $<0.001$ & $<0.001$ & $<0.001$ \\
\hline \multicolumn{2}{|c|}{ Species $\times Z n$ levels } & $<0.001$ & $<0.001$ & $<0.001$ & $<0.001$ & $<0.001$ \\
\hline
\end{tabular}

Note: Different letters (a, b, c) indicate significant difference at $P \leqslant 0.05$ among different $\mathrm{Zn}$ supply level at the same species

Table 2: Effects of different $\mathrm{Zn}$ supply levels on photosynthetic characteristics of rape

\begin{tabular}{|c|c|c|c|c|c|}
\hline Species & $\begin{array}{l}\text { Zn supply levels } \\
\left(\mathrm{mg} \mathrm{kg}^{-1}\right)\end{array}$ & $\begin{array}{l}\text { Net photosynthetic rate } \\
\left(\mu \mathrm{mol} \mathrm{m} \mathrm{s}^{-1}\right)\end{array}$ & $\begin{array}{l}\text { Stomatal conductance } \\
\left(\mathrm{mol} \mathrm{m}^{-2} \mathrm{~s}^{-1}\right)\end{array}$ & $\begin{array}{l}\text { Transpiration rate/ } \\
\left(\mathrm{mol} \mathrm{m}^{-2} \mathrm{~s}^{-1}\right)\end{array}$ & $\begin{array}{l}\text { Intercellular } \mathrm{CO}_{2} \text { concentration } \\
\left(\mu \mathrm{mol} \mathrm{mol}^{-1}\right)\end{array}$ \\
\hline \multirow[t]{5}{*}{ B. napus } & 0 & $9.01 \pm 0.73 \mathrm{e}$ & $0.20 \pm 0.03 \mathrm{bc}$ & $4.77 \pm 0.31 \mathrm{e}$ & $275.89 \pm 5.03 \mathrm{~b}$ \\
\hline & 1 & $9.88 \pm 0.69 \mathrm{~d}$ & $0.22 \pm 0.05 b$ & $5.49 \pm 0.47 \mathrm{~b}$ & $272.32 \pm 7.03 \mathrm{c}$ \\
\hline & 5 & $11.69 \pm 0.59 \mathrm{c}$ & $0.25 \pm 0.02 \mathrm{a}$ & $5.83 \pm 0.21 \mathrm{a}$ & $235.28 \pm 5.03 \mathrm{~d}$ \\
\hline & 10 & $12.76 \pm 0.83 b$ & $0.19 \pm 0.03 \mathrm{c}$ & $4.95 \pm 0.30 \mathrm{~d}$ & $276.42 \pm 5.03 b$ \\
\hline & 20 & $14.65 \pm 1.21 \mathrm{a}$ & $0.26 \pm 0.05 \mathrm{a}$ & $5.06 \pm 0.59 \mathrm{c}$ & $284.69 \pm 5.03 \mathrm{a}$ \\
\hline \multirow[t]{5}{*}{ B. juncea } & 0 & $7.99 \pm 0.57 \mathrm{~d}$ & $0.21 \pm 0.03 \mathrm{~cd}$ & $3.12 \pm 0.15 \mathrm{~d}$ & $329.33 \pm 5.03 \mathrm{c}$ \\
\hline & 1 & $9.64 \pm 0.62 b$ & $0.34 \pm 0.04 \mathrm{~b}$ & $4.48 \pm 0.40 \mathrm{~b}$ & $318.87 \pm 5.03 \mathrm{~d}$ \\
\hline & 5 & $11.53 \pm 0.47 \mathrm{a}$ & $0.39 \pm 0.07 \mathrm{a}$ & $4.81 \pm 0.43 \mathrm{a}$ & $304.12 \pm 5.03 \mathrm{e}$ \\
\hline & 10 & $9.16 \pm 0.52 c$ & $0.24 \pm 0.02 \mathrm{c}$ & $3.96 \pm 0.23 \mathrm{c}$ & $342.09 \pm 5.03 \mathrm{~b}$ \\
\hline & 20 & $7.21 \pm 0.34 \mathrm{e}$ & $0.16 \pm 0.03 \mathrm{~d}$ & $2.69 \pm 0.17 \mathrm{e}$ & $398.93 \pm 5.03 \mathrm{a}$ \\
\hline \multirow[t]{5}{*}{ B. campestris } & 0 & $13.17 \pm 0.79 \mathrm{~d}$ & $0.28 \pm 0.06 \mathrm{~b}$ & $5.79 \pm 0.61 \mathrm{e}$ & $308.15 \pm 5.03 b$ \\
\hline & 1 & $14.72 \pm 0.53 \mathrm{c}$ & $0.30 \pm 0.07 \mathrm{ab}$ & $6.21 \pm 0.50 \mathrm{c}$ & $297.37 \pm 5.03 c$ \\
\hline & 5 & $16.64 \pm 1.32 \mathrm{a}$ & $0.35 \pm 0.0 .4 \mathrm{a}$ & $6.97 \pm 0.73 \mathrm{a}$ & $285.25 \pm 5.03 \mathrm{e}$ \\
\hline & 10 & $15.05 \pm 0.95 \mathrm{~b}$ & $0.30 \pm 0.03 \mathrm{ab}$ & $5.50 \pm 0.43 \mathrm{e}$ & $295.14 \pm 5.03 d$ \\
\hline & 20 & $14.62 \pm 1.47 \mathrm{~cd}$ & $0.33 \pm 0.05 \mathrm{a}$ & $6.69 \pm 0.65 b$ & $314.76 \pm 5.03 \mathrm{a}$ \\
\hline \multicolumn{6}{|l|}{$\operatorname{Probability}(P)$} \\
\hline Species & & $<0.001$ & 0.002 & $<0.001$ & $<0.001$ \\
\hline Zn levels & & $<0.001$ & $<0.001$ & $<0.001$ & $<0.001$ \\
\hline Species $\times Z n$ levels & & $<0.001$ & $<0.001$ & $<0.001$ & $<0.001$ \\
\hline
\end{tabular}

Note: Different letters (a, b, c) indicate significant difference at $P \leqslant 0.05$ among different $\mathrm{Zn}$ supply level at the same species

B. campestris and B. napus was higher than that in B. juncea at the same $\mathrm{Zn}$ supply level. Significant difference of $\mathrm{Ci}$ in leaf of rape was observed among different species and $\mathrm{Zn}$ supply levels $(p<0.05)$. The maximum $\mathrm{Ci}$ of leaf in three species was found at $\mathrm{Zn}$ supply level of $20.0 \mathrm{mg} \mathrm{kg}^{-1}$ with the enhancement by $3.2 \%, 21.3 \%$ and $2.3 \%$ when compared with the controls, respectively.

\section{Photosynthetic Characteristics}

As shown in Table 2, significant difference of transpiration rate $(\mathrm{Tr})$ in leaf was found among rape species and $\mathrm{Zn}$ supply levels $(p<0.05)$. The maximum $\mathrm{Tr}$ in rape species was observed at $\mathrm{Zn}$ supply level of $5.0 \mathrm{mg}$ $\mathrm{kg}^{-1}$ with the increase by $22.2 \%, 54.2 \%$ and $20.4 \%$ when compared with the control, respectively. Tr in leaf of $B$. campestris and B. napus was higher than that in B. juncea at the same $\mathrm{Zn}$ supply level. Significant difference of $\mathrm{Ci}$ in leaf of rape was observed among different species and $\mathrm{Zn}$ supply levels $(p<0.05)$. The maximum $\mathrm{Ci}$ of leaf in three species was found at $\mathrm{Zn}$ supply level of $20.0 \mathrm{mg} \mathrm{kg}^{-1}$ with the enhancement by $3.2 \%, 21.3 \%$ and $2.3 \%$ when compared with the controls, respectively.

\section{Root Exudates}

The contents and species qualitative and quantitative analyses of amino acids in root exudates of rape revealed an obvious difference among species and between $\mathrm{Zn}$ supply levels (Table 3). The contents of 14 kinds of amino acids in 
Table 3: Effect of zinc supply levels on amino acid contents in roots of rape (ug $100 \mathrm{~mL}^{-1}$ )

\begin{tabular}{|c|c|c|c|c|c|c|}
\hline \multirow{2}{*}{$\begin{array}{l}\text { Treatment } \\
\text { Amino acids }\end{array}$} & \multicolumn{3}{|c|}{$1.0 \mathrm{mg} \mathrm{kg}^{-1} \mathrm{Zn}$} & \multicolumn{3}{|c|}{$20.0 \mathrm{mg} \mathrm{kg}^{-1} \mathrm{Zn}$} \\
\hline & B.napus & B. juncea & B. campestris & B. napus & B. juncea & B. campestris \\
\hline Aspartic & $129 \pm 9 a$ & $149 \pm 12 a$ & $\mathrm{Nd} \pm 0 \mathrm{~b}$ & $98 \pm 5 b$ & $142 \pm 11 \mathrm{a}$ & $100 \pm 5 \mathrm{c}$ \\
\hline Threonine & $107 \pm 3 b$ & $137 \pm 9 a$ & $\mathrm{Nd} \pm 0 \mathrm{c}$ & $82 \pm 5 c$ & $155 \pm 17 \mathrm{a}$ & $106 \pm 8 \mathrm{~b}$ \\
\hline Serine & $\mathrm{Nd} \pm 00 \mathrm{~b}$ & $\mathrm{Nd} \pm 0 \mathrm{~b}$ & $32 \pm 2 \mathrm{a}$ & $96 \pm 2 a$ & $110 \pm 5 \mathrm{a}$ & $90 \pm 1 \mathrm{a}$ \\
\hline Glutamic & $572 \pm 15 \mathrm{ab}$ & $699 \pm 25 a$ & $48 \pm 1 b$ & $219 \pm 9 b$ & $501 \pm 23 a$ & $492 \pm 15 \mathrm{a}$ \\
\hline Glycine & $92 \pm 6 \mathrm{a}$ & $\mathrm{Nd} \pm 0 \mathrm{~b}$ & $\mathrm{Nd} \pm 0 \mathrm{~b}$ & $81 \pm 5 a$ & $71 \pm 9 \mathrm{a}$ & $12 \pm \pm 1 b$ \\
\hline Alanine & $151 \pm 11 \mathrm{a}$ & $121 \pm 14 \mathrm{a}$ & $50 \pm 3 \mathrm{~b}$ & $106 \pm 8 b$ & $181 \pm 15 \mathrm{a}$ & $122 \pm 9 a b$ \\
\hline Cysteine & $\mathrm{Nd} \pm 0 \mathrm{a}$ & $\mathrm{Nd} \pm 0 \mathrm{a}$ & $\mathrm{Nd} \pm 0 \mathrm{a}$ & $\mathrm{Nd} \pm 0 \mathrm{a}$ & $467 \pm 21 \mathrm{a}$ & $\mathrm{Nd} \pm 0 \mathrm{a}$ \\
\hline Valine & $\mathrm{Nd} \pm 0 \mathrm{a}$ & $\mathrm{Nd} \pm 0 \mathrm{a}$ & $\mathrm{Nd} \pm 0 \mathrm{a}$ & $\mathrm{Nd} \pm 0 \mathrm{a}$ & $357 \pm 15 \mathrm{a}$ & $\mathrm{Nd} \pm 0 \mathrm{~b}$ \\
\hline Methionine & $710 \pm 33 a$ & $670 \pm 29 \mathrm{ab}$ & $506 \pm 18 b$ & $1034 \pm 34 a$ & $616 \pm 12 b$ & $664 \pm 9 \mathrm{~b}$ \\
\hline Isoleucine & $209 \pm 4 a$ & $238 \pm 11 \mathrm{a}$ & $240 \pm 9 a$ & $215 \pm 6 b$ & $353 \pm 0 \mathrm{a}$ & $\mathrm{Nd} \pm 0 \mathrm{c}$ \\
\hline Leucine & $216 \pm 15 a$ & $199 \pm 3 a$ & $73 \pm 2 b$ & $235 \pm 9 a$ & $263 \pm 15 a$ & $\mathrm{Nd} \pm 0 \mathrm{~b}$ \\
\hline Tyrosine & $\mathrm{Nd} \pm 0 \mathrm{a}$ & $\mathrm{Nd} \pm 0 \mathrm{a}$ & $\mathrm{Nd} \pm 00 \mathrm{a}$ & $\mathrm{Nd} \pm 0 \mathrm{a}$ & $\mathrm{Nd} \pm 0 \mathrm{a}$ & $\mathrm{Nd} \pm 0 \mathrm{a}$ \\
\hline Phenylalanine & $679 \pm 34 a b$ & $712 \pm 25 \mathrm{a}$ & $582 \pm 13 b$ & $771 \pm 23 \mathrm{a}$ & $765 \pm 17 \mathrm{a}$ & $\mathrm{Nd} \pm 0 \mathrm{~b}$ \\
\hline Lysine & $1451 \pm 42 \mathrm{a}$ & $1470 \pm 36 \mathrm{a}$ & $257 \pm 9 b$ & $1783 \pm 36 a$ & $735 \pm 14 b$ & $701 \pm 11 b$ \\
\hline Histidine & $\mathrm{Nd} \pm 0 \mathrm{a}$ & $\mathrm{Nd} \pm 0 \mathrm{a}$ & $\mathrm{Nd} \pm 0 \mathrm{a}$ & $\mathrm{Nd} \pm 0 \mathrm{a}$ & $\mathrm{Nd} \pm 0 \mathrm{a}$ & $\mathrm{Nd} \pm 0 \mathrm{a}$ \\
\hline Arginine & $54 \pm 3 b$ & $139 \pm 9 a$ & $\mathrm{Nd} \pm 0 \mathrm{c}$ & $\mathrm{Nd} \pm 0 \mathrm{~b}$ & $56 \pm 3 a$ & $\mathrm{Nd} \pm 0 \mathrm{~b}$ \\
\hline Proline & $\mathrm{Nd} \pm 0 \mathrm{a}$ & $\mathrm{Nd} \pm 0 \mathrm{a}$ & $\mathrm{Nd} \pm 0 \mathrm{a}$ & $\mathrm{Nd} \pm 0 \mathrm{a}$ & $\mathrm{Nd} \pm 0 \mathrm{a}$ & $\mathrm{Nd} \pm 0 \mathrm{a}$ \\
\hline Total & $4370 \pm 67 a$ & $4534 \pm 54 a$ & $1788 \pm 13 b$ & $4720 \pm 44 a$ & $4772 \pm 39 a$ & $2287 \pm 17 b$ \\
\hline
\end{tabular}

Note: Nd represents not detected $\left(<0.001, \mathrm{mg}^{\bullet} 100 \mathrm{~mL}^{-1}\right)$; Different letters $(\mathrm{a}, \mathrm{b}, \mathrm{c})$ indicate significant difference at $P \leqslant 0.05$ among different species at the same Zn supply level

root exudates of rape were in the range of $0.012-1.783$ $\mathrm{mg} 100 \mathrm{~mL}^{-1} \mathrm{FW}$ in the presence of 1.0 and $20.0 \mathrm{mg} \mathrm{kg}^{-1}$ $\mathrm{Zn}$. Moreover, glutamic acid, methionine, leucine, phenylalanine and lysine were the major amino acids in root exudates of rape with $4.6-21.5 \%, 12.9-29.0 \%, 4.1-5.5 \%$, $15.5-32.6 \%$ and $14.4-37.8 \%$ of total amount of amino acids, respectively. Whether in the presence of 1.0 or 20.0 $\mathrm{mg} \mathrm{kg}{ }^{-1} \mathrm{Zn}, 11$ kinds of amino acids were detected in root exudates of $B$. napus, but only 8 kinds of amino acids were detected in root exudates of $B$. campestris. In root exudates of $B$. juncea, 11 kinds of amino acids were detected in the presence of $1.0 \mathrm{mg} \mathrm{kg}^{-1} \mathrm{Zn}$, while 14 kinds of amino acids were detected in the presence of $20.0 \mathrm{mg} \mathrm{kg}^{-1}$ $\mathrm{Zn}$. Whether in the presence of 1.0 or $20.0 \mathrm{mg} \mathrm{kg}^{-1} \mathrm{Zn}$, the total amino acid content in root exudates of $B$. juncea and $B$. napus species was significantly higher than that in root exudates of B. campestris. As seen in the Table 3, the application of $\mathrm{Zn}$ could improve the total amount of amino acids in root exudates of rape with the enhancement by 8.01, 5.25 and $27.9 \%$ when compared with the $\mathrm{Zn}$ treatments of $1.0 \mathrm{mg} \mathrm{kg}^{-1}$, respectively. However, $\mathrm{Zn}\left(20 \mathrm{mg} \mathrm{kg}^{-1}\right)$ resulted in two changes including the increase of serine, methionine, isoleucine, leucine, phenylalanine and lysine content, and the reduction of aspartic acid, threonine, glutamic acid and glycine content.

\section{Ultrastructure of Root Tip Cells}

Fig. 5 shows the root tip cell ultrastructure of rape species in the presence of 1.0 and $20.0 \mathrm{mg} \mathrm{kg}^{-1} \mathrm{Zn}$ during the period of flowering. Obvious differences of root tip cell ultrastructure were observed in the presence of 1.0 and $20.0 \mathrm{mg} \mathrm{kg}^{-1} \mathrm{Zn}$. At the $\mathrm{Zn}$ treatments of $1.0 \mathrm{mg} \mathrm{kg}^{-1}$, root tip cells of all species revealed the integral structure, small gap, and normal differentiation of organelles; meanwhile, rich cell



Fig. 1: Effects of different $\mathrm{Zn}$ supply levels on stem dry weights of rape

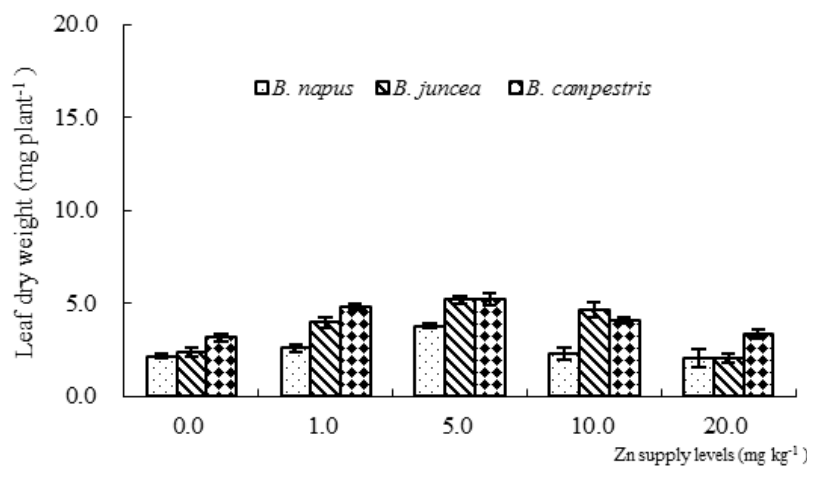

Fig. 2: Effects of different Zn supply levels on leaf dry weights of rape

contents, and obvious differentiation of cell wall between primary cells and secondary cells, typical ultrastructure of mitochondria with normal shape and matrix were also observed (Fig. 5A, B and C). At the $\mathrm{Zn}$ treatments of 


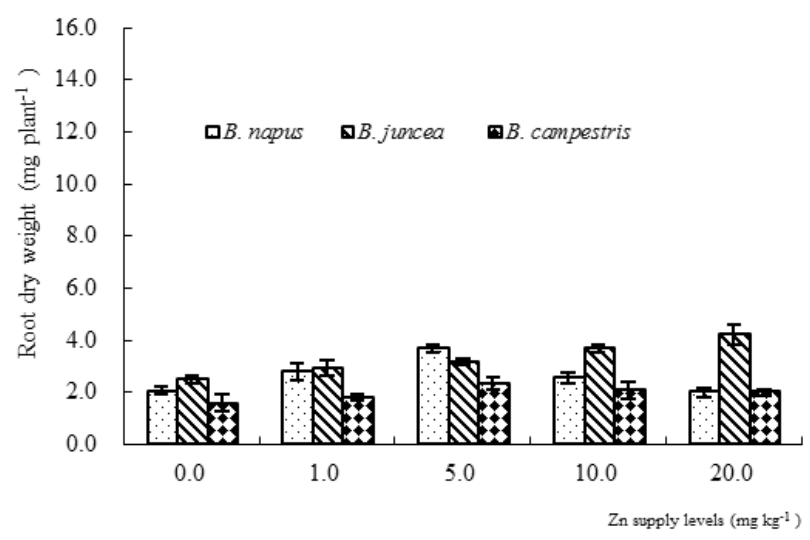

Fig. 3: Effects of different Zn supply levels on root dry weights of rape

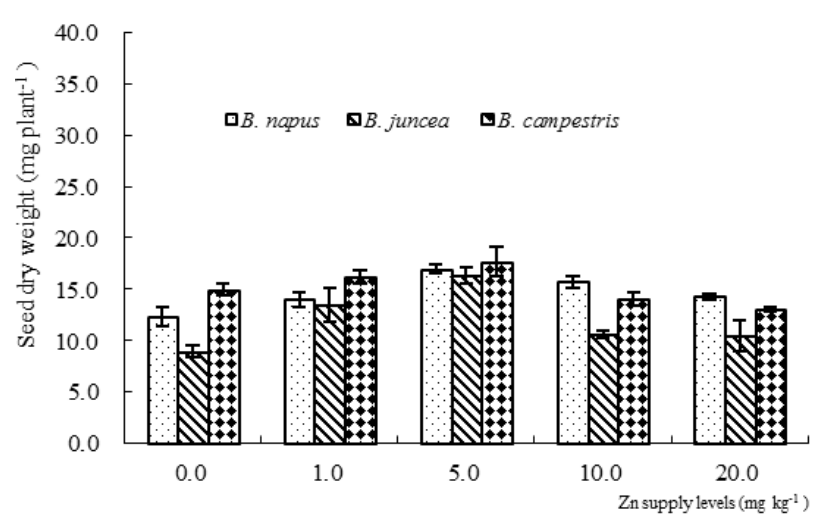

Fig. 4: Effects of different Zn supply levels on seed dry weights of rape

$20.0 \mathrm{mg} \mathrm{kg}^{-1}$, mitochondrial swelling, cell wall thickening and cell content lessening in root tip cell ultrastructure were observed in B. napus (Fig. 5D); meanwhile, the obvious lack of cell contents, uneven thickening of cell wall, and the shrinking of nuclei in root tip cell ultrastructure were observed in B. juncea (Fig. 5E); however, no obvious differences of root tip cell structure were found in $B$. campestris between 1.0 and $20.0 \mathrm{mg} \mathrm{kg}^{-1} \mathrm{Zn}$ treatments, except slight mitochondrial swelling in root tip cells at the $\mathrm{Zn}$ treatments of $20.0 \mathrm{mg} \mathrm{kg}^{-1}$ (Fig. 5F).

\section{Concentration of $\mathbf{Z n}$}

Significant differences of $\mathrm{Zn}$ concentration in seeds, leaves, stems and roots of rape were observed among different species $(p<0.05)$, Zn supply levels and significant interaction of $\mathrm{Zn}$ concentration in seeds, leaves, stems and roots between species and $\mathrm{Zn}$ levels $(p<0.05)$ (Figs. 6$9)$. The $\mathrm{Zn}$ concentration revealed an order as seeds $>$ leaves or stems $>$ roots. As the increase of $\mathrm{Zn}$ supply level, the concentrations of $\mathrm{Zn}$ in different tissues or parts of rape revealed an increasing trend. At the present $\mathrm{Zn}$ treatments, $\mathrm{Zn}$ concentrations in seeds, leaves, stems
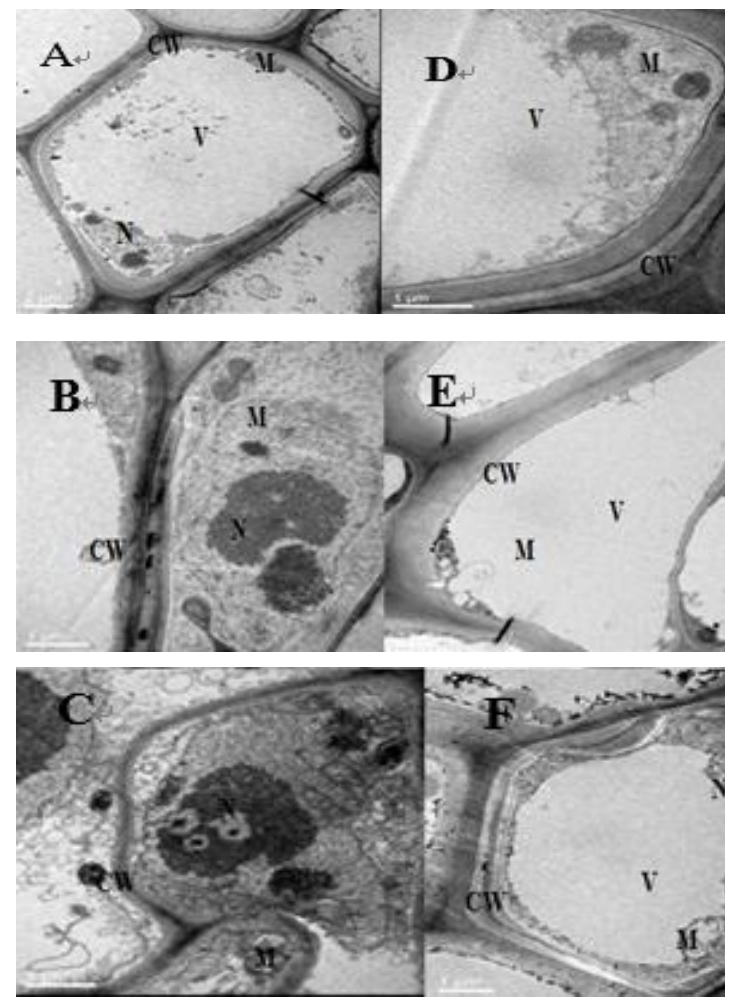

Fig. 5: Ultrastructure of root tip cells in rape species subjected to different $\mathrm{Zn}$ supply levels

Note: A, B and C are the ultrastructure of root tip cells in B. napus, B. juncea and $B$. campestris with zinc treatment at the concentration of 1.0 $\mathrm{mg} \mathrm{kg}^{-1} ; \mathrm{D}, \mathrm{E}$ and $\mathrm{F}$ are the ultrastructure of root tip cells in B. napus, YR and $B$. campestris with zinc treatment at the concentration of $20.0 \mathrm{mg} \mathrm{kg}^{-1}$, respectively. $\mathrm{N}$, nuclei; $\mathrm{M}$, mitochondria; $\mathrm{V}$, bubble; $\mathrm{CW}$, cell wall

and roots of rape species increased by $8.0-18.6 \%, 14.2-$ $103.8 \%, 11.0-135.8 \%$ and $21.2-423.2 \%$ compared to the control, respectively. Compared with the three rape species, seed $\mathrm{Zn}$ concentrations in B. napus were higher than that in B. campestris and B. juncea species.

\section{Discussion}

Zinc is an essential element for plant growth which plays a fundamental role in several critical functions. The recent experiments have been found that the dry weight of the three rape species revealed a gradual increasing trend as the increase of $\mathrm{Zn}$ supply level, when $\mathrm{Zn}$ supply level was less than $5.0 \mathrm{mg} \mathrm{kg}^{-1}$. This result is consistent with the results of $\mathrm{Xu}$ et al. (2005) and Rehman et al. (2012). Zinc is not only an essential element for the growth and development of plants, but also a heavy metal (Kösesakal and Ünal, 2009). Stoyanova and Doncheva's (2002) reported that $\mathrm{Zn}$ supplied at levels above $70 \mathrm{mM}$ produced toxic effects typical of metal stress in pea (Pisum sativum L., cv. Citrine) and led to a reduction in the root, stem and leaf growth. In our study, the dry weight (stem, leaf and seed) of rape 


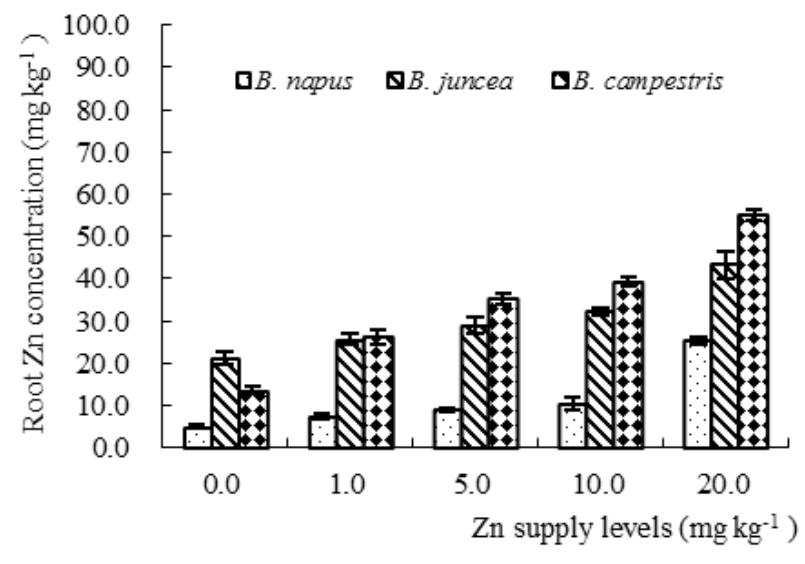

Fig. 6: Effects of different $\mathrm{Zn}$ supply levels on root $\mathrm{Zn}$ concentration of rape

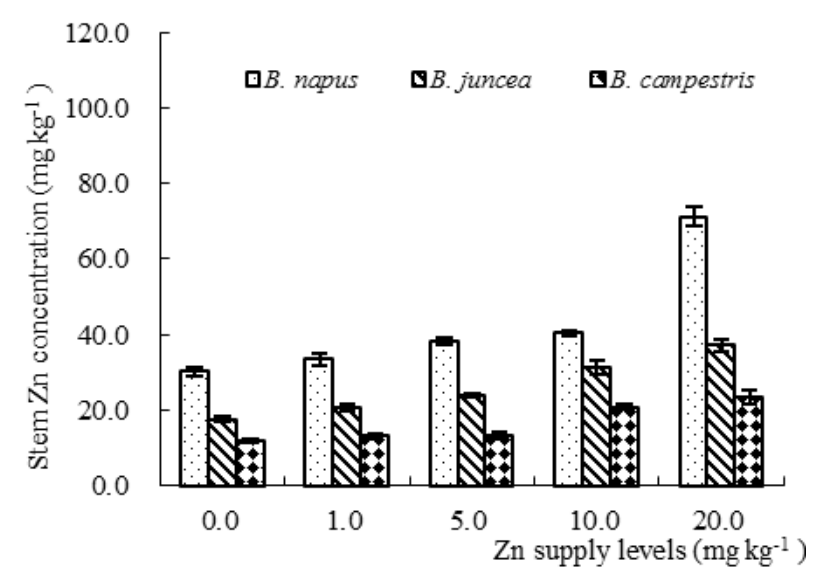

Fig. 7: Effects of different $\mathrm{Zn}$ supply levels on stem $\mathrm{Zn}$

species reveal a decreasing trend when $\mathrm{Zn}$ supplied at levels above $10.0 \mathrm{mg} \mathrm{kg}^{-1}$ due to high level of $\mathrm{Zn}$ inhibiting the absorption and utilization of nutrients.

The antioxidant enzymes such as SOD, POD and CAT can scavenge stress-induced active oxygen. As the scavengers of active oxygen in plants, these antioxidant enzymes can effective eliminate free radicals and peroxides in plants. In the present study, the activities of SOD, CAT and POD in leaf of B. napus are lower at low $\mathrm{Zn}$ supply level due to the normal growth of plants; in contrast, the excessive $\mathrm{Zn}$ increased activities of three antioxidant enzymes for reducing $\mathrm{Zn}$ stress-induced cell damage. When $\mathrm{Zn}$ supply level is up to $20.0 \mathrm{mg} \mathrm{kg}^{-1}$, the activities of SOD, CAT and POD could not continue to increase for relieving stress environment, which is consistent with the similar results from the studies of Xu et al. (2005) and Jiang et al. (2009). On the other hand, compared to B. napus, B. juncea and $B$. campestris still maintain high activities of SOD and CAT in response to the ultra-high stress from excessive $\mathrm{Zn}$ (20.0 mg kg $\mathrm{g}^{-1}$ ), indicating that the two rape species have strong tolerance to $\mathrm{Zn}$.

Free proline content in plants is the biomarker for

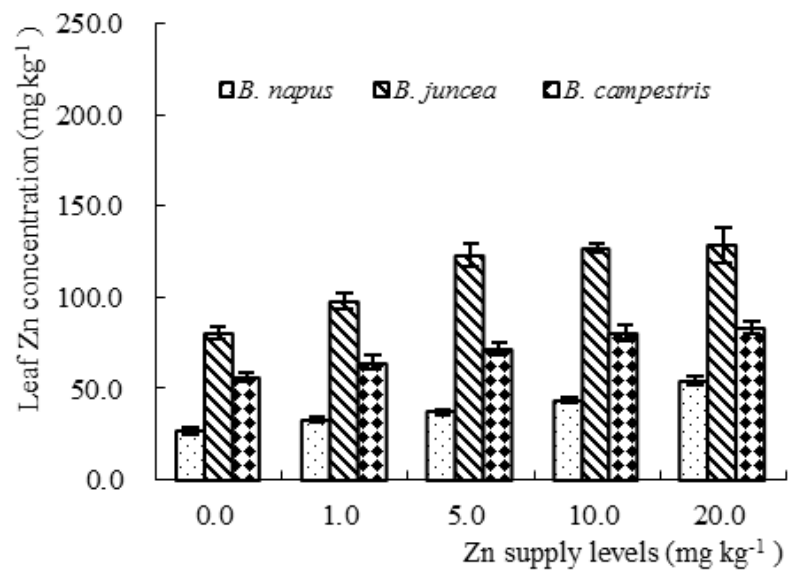

Fig. 8: Effects of different $\mathrm{Zn}$ supply levels on leaf $\mathrm{Zn}$ concentration of rape

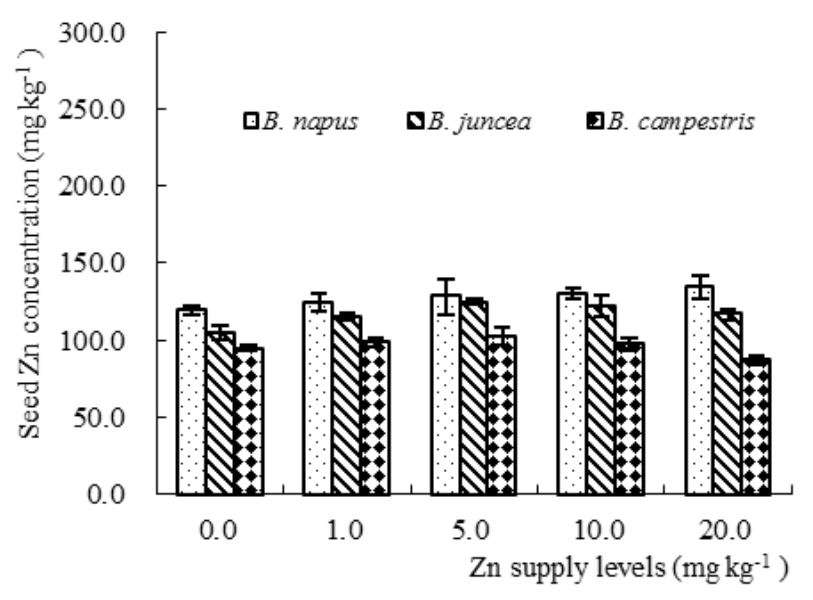

Fig. 9: Effects of different $\mathrm{Zn}$ supply levels on seed $\mathrm{Zn}$ concentration of rape

physiological and biochemical responses to the stress from environments (Smirnoff, 1993). The alteration of proline content can reflect the adaptation degree of plants to environments. In the present study, proline contents in leaf of rape species revealed an initial decrease and a final increase with the increase of $\mathrm{Zn}$ supply level, and reached to the lowest at $\mathrm{Zn}$ supply level of $5.0 \mathrm{mg} \mathrm{kg}^{-1}$. Proline content in leaf of rape species reached to the peak at $\mathrm{Zn}$ supply level of $20.0 \mathrm{mg} \mathrm{kg}^{-1}$, suggesting excessive $\mathrm{Zn}\left(20.0 \mathrm{mg} \mathrm{kg}^{-1}\right)$ induced the increase of proline content in leaf of rape in response to $\mathrm{Zn}$ stress. This result is consistent with the conclusion from the studies of $\mathrm{Xu}$ et al. (2005) and Ramakrishna and Rao (2012).

MDA is the final product of lipid peroxidation, and can interfere with normal physiological metabolism of plant cells through relaxing bridge bonds between cellulose molecules and inhibiting protein synthesis during the interaction between proteins and nucleic acids. The increased MDA content can reflect the stress-induced damage of plants (Sun et al., 2011). In our study, MDA 
content gradually decreased with the increase of Zn supply level. When $\mathrm{Zn}$ level is higher than $10.0 \mathrm{mg} \mathrm{kg}^{-1}$, MDA content shows an upward trend and reached up to the peak level at $\mathrm{Zn}$ supply level of $20.0 \mathrm{mg} \mathrm{kg}$. These results suggest that low $\mathrm{Zn}$ is benefit for the growth of plants; in contrast, excessive $\mathrm{Zn}$ can induce $\mathrm{Zn}$ stress and result in increasing MDA content and influencing the normal growth of plants and same trend was reported by Panda and Choudhury (2005).

The deficiency of $\mathrm{Zn}$ affects plant growth and inhibit photosynthesis intensity. In the present study, $\mathrm{Zn}(\leq 5.0 \mathrm{mg}$ $\mathrm{kg}^{-1}$ ) increased $\mathrm{Pn}$, Gs and $\mathrm{Tr}$ in leaf of rape species, suggesting that $\mathrm{Zn}$ at low level can improve photosynthetic capacity in plants and productivity and normal energy utilization, and promote normal growth of plants. However, when $\mathrm{Zn}$ supply level was higher than $10.0 \mathrm{mg} \mathrm{kg}^{-1}$, Pn, Gs and $\mathrm{Tr}$ in leaf of rape species showed a downward trend due to $\mathrm{Zn}$ stress. This result is consistent with the results from the research of Nguyen-Deroche et al. (2012). Meanwhile, the experiments have found that Pn, Gs and Tr in leaf of $B$. napus and $B$. campestris are higher than those in $B$. juncea at $\mathrm{Zn}$ supply level of $20.0 \mathrm{mg} \mathrm{kg}{ }^{-1}$, maybe due to their high resistance to $\mathrm{Zn}$ stress. Many studies have demonstrated that $\mathrm{Zn}$ can reduce $\mathrm{Ci}$ and $\mathrm{Gs}$, and inhibit the activity of carbonic anhydrase, thus affecting photosynthetic capacity. In the present study, under the condition with $\mathrm{Zn}$ at high supply level, both Pn and Gs in leaf of rape reveal an obvious decline, indicating that Gs in leaf of rape is the factor for limiting photosynthetic capacity. According to the theoretical analysis, $\mathrm{Ci}$ should be reduced to decrease the photosynthetic rate during the decrease of Gs. However, low photosynthetic rate is accompanied by increased $\mathrm{Ci}$, indicating that the effect of $\mathrm{Zn}$ supply level on photosynthetic rate in rape species is due to the nonstomatal factors such as reduced photosynthetic activity in cells, inhibited RUBP carboxylase, or suppressed Calvin cycle as well as other factors.

A large number of experimental studies show that root exudates can change the soil environment by regulating $\mathrm{pH}$ value, precipitation, stability and chelating, so as to affect the plant's absorption and utilization of nutrients (Yang et $a l ., 2011)$. In the present study, high supply level of $\mathrm{Zn}(20.0$ $\mathrm{mg} \mathrm{kg}^{-1}$ ) promote the secretion of more amino acids. This result is similar to the reports of Yang et al. (2011). Different plant species or varieties have different absorption capacity of $\mathrm{Zn}$. The differences of plant $\mathrm{Zn}$ gene genotypes were different not only in root morphology, but also in root exudates (Hajiboland et al., 2003). In our study, the total amino acid content of root exudates in $B$. juncea and $B$. napus was significantly higher than that of $B$. campestris at the $\mathrm{Zn}$ treatments of 1.0 and $20.0 \mathrm{mg} \mathrm{kg}^{-1}$, and $11 \mathrm{kinds}$ of amino acids were detected in root exudates of $B$. napus and $B$. juncea, and only 8 kinds of amino acids were detected in root exudates of $B$. campestris. High $\mathrm{Zn}$ concentration in $B$. napus may be due to more root exudates in $B$. napus, which could increase rhizosphere $\mathrm{Zn}$ mobility and effectiveness. Zinc concentration in Zn-high-efficiency species or varieties is related to the absorption capacity of the plant's roots and the ability to change soil $\mathrm{Zn}$ availability (Dong et al., 1995).

\section{Conclusion}

Zinc $\left(C \mathrm{Zn}^{2+} \leq 5.0 \mathrm{mg} \mathrm{kg} \mathrm{kg}^{-1}\right)$ increased the activities of antioxidant enzymes, net photosynthetic rate $\left(\mathrm{P}_{\mathrm{n}}\right)$, stomatal conductance $\left(\mathrm{G}_{\mathrm{s}}\right)$, transpiration rate $\left(\mathrm{T}_{\mathrm{r}}\right)$ in leaf, and dry weights of plant. The dry weight (stem, leaf and seed) of rape species reveal a decreasing trend when $\mathrm{Zn}$ supplied at levels above $10.0 \mathrm{mg} \mathrm{kg}$. As the increase of $\mathrm{Zn}$ supply level, the concentrations of $\mathrm{Zn}$ in seed of rape revealed an increasing trend. The best $\mathrm{Zn}$ supply level for having more biomass and more $\mathrm{Zn}$ in seeds of rape without toxic effects was observed at $10.0 \mathrm{mg} \mathrm{kg}^{-1}$. The content of amino acid of root exudates in YR and $B$. napus was significantly higher than that of $B$. campestris in the presence of $\mathrm{Zn}$. The highest of $\mathrm{Zn}$ concentration in seed were observed in B. napus may be due to due to more root exudates.

\section{Acknowledgments}

This work was supported by Fund of China Agriculture Research System (Nycytx-35-gw16 and by the National Natural Science Foundation of China (No.31372141; 31672238). The first author gratefully thanks Dr. Hong Li at Lancaster Environment Centre, Lancaster University for reviewing the manuscript.

\section{References}

Alloway, B.J., 2008. Zinc in Soils and Crop Nutrition, $2^{\text {nd }}$ edition, p: 45. International Zinc Association, Brussels, Belgium and Paris, France

Bates, L.S., R.P. Waldren, I.D. and Teare, 1973. Rapid determination of free praline for water stress studies. Plant Soil, 39: 205-208

Bird, R.P., S.S. Hung, M. Hadley and M. Draper, 1983. Determination of malonaldehyde in biological materials by high-pressure liquid chromatography. Anal. Biochem., 128: 240-244

Coolong, T.W. and W.M. Randle, 2003. Zinc concentration in hydroponic solution culture influences zinc and sulfur accumulation in Brassica rapa L. J. Plant Nutr., 26: 949-959

Dong, B., Z. Rengel and R.D. Graham, 1995. Root morphology of wheat genotypes differing in zinc efficiency. J. Plant Nutr., 18: 2761-2773

Erenoglu, B., V. Römheld and I. Cakmak, 2001. Retranslocation of zinc from older leaves to younger leaves and roots in wheat cultivars differing in zinc efficiency. In: Plant nutrition-food security and sustainability of agro-ecosystems, pp: 224-225.

Horst, W.J., M.K. Schenk, A. Bürkert, N. Claassen, H. Flessa, W.B. Frommer, H. Goldbach, H.W. Olfs, V. Römheld, B. Sattelmacher, U. Schmidhalter, S. Schubert, N.V. Wirén and L. Wittenmayer (eds.). Kluwer Academic Publishers, Dordrecht, The Netherlands

Ghasemi, S., A.H. Khoshgoftarmanesh, M. Afyuni and H. Hadadzadehb, 2013. The effectiveness of foliar applications of synthesized zincamino acid chelates in comparison with zinc sulphate to increase yield and grain nutritional quality of wheat. Eur. J. Agron., 45: 6874

Glińska, S. and B. Gabara, 2000. Changes in the ultrastructure of meristematic root cells of Allium sativum L. treated with selenium. Acta Soc. Bot. Polonica, 69: 93-100 
Gomez-Coronado, F., M.J. Poblaciones, A.S. Almeida and I. Cakmak, 2015. Zinc $(\mathrm{Zn})$ concentration of bread wheat grown under Mediterranean conditions as affected by genotype and soil/foliar $\mathrm{Zn}$ application. Plant Soil, 40: 1-16

Hajiboland, R., X.E. Yang and V. Römheld, 2003. Effects of bicarbonate and high $\mathrm{pH}$ on growth of $\mathrm{Zn}$-effcient and $\mathrm{Zn}$-ineffcient genotypes of rice, wheat and rye. Plant Soil, 250: 349-357

Hansen, B.H., S. Romma, O.A. Garmo, P.A. Olsvik and R.A. Andersen, 2006. Antioxidative stress proteins and their gene expression in brown trout (Salmo trutta) from three rivers with different heavy metal levels. Comparative Biochem. Physiol. Part C: Toxicol. Pharmacol., 143: 263-274

Jiang, Z.H., B.Q. Weng, J.G. Lei, Y.X. Wang, X.Q. Tang and S.X. Xiao, 2009. Effect of exogenous zinc addition on cell protective enzyme activities in the fruit bodies of Lentinus giganteus. Acta Microbiol. Sin., 49: 1121-1125

Kösesakal, T. and M. Ünal, 2009. Role of zinc deficiency in photosynthetic pigments and peroxidase activity of tomato seedlings. IUFS J. Biol., 68: $113-120$

Levenson, C.W. and D. Morris, 2011. Zinc and neurogenesis: making new neurons from development to adulthood. Adv. Nutr., 2: 96-100

McLeod, S. 1975. Studies in wet oxidation procedures for the determination of 'organic C' in soil. In: "Notes on soil Techniques", pp. 73-79. Division of Soils, Adelaide, CSIRO, Canberra, Australia

Minami,M. andH. Yoshikawa, 1979. A simplified assay method of superoxide dismutase activity for clinical use. Clin. Chem. Acta, 92: 337-342

Nakano, Y. and K. Asada, 1981. Hydrogen peroxide is scavenged by ascorbate-specific peroxidase in spinach chloroplasts. Plant Cell Physiol., 22: 867-880

Nguyen-Deroche, T.N., A. Caruso, T.T. Le, T.V. Bui, B. Schoefs, G. Tremblin and A. Morant-Manceau, 2012. Zinc affects differently growth, photosynthesis, antioxidant enzyme activities and phytochelatin synthase expression of four marine diatoms. Sci. World J., 2012: 982957

Panda, S.K. and S. Choudhury, 2005. Changes in nitrate reductase activity and oxidative stress response in the moss Polytrichum commune subjected to chromium, copper and zinc phytotoxicity. Braz. J. Plant Physiol., 17: 191-197

Poblaciones, M.J. and Z. Rengel, 2016. Soil and foliar zinc biofortification in field pea (Pisum sativum L.): grain accumulation and bioavailability in raw and cooked grains. Food Chem., 212: 427-433
Ramakrishna, B. and S.S.R. Rao, 2012. 24-Epibrassinolide alleviated zincinduced oxidative stress in radish (Raphanus sativus L.) seedlings by enhancing antioxidative system. Plant Growth Regul., 68: 249259

Rayment, G.E. and F.R. Higginson, 1992. Australian Laboratory Handbook of Soil and Water Chemical Methods. Inkata Press, Melbourne

Rehman, H., T. Aziz, M. Farooq, A. Wakeel and Z. Rengel, 2012. Zinc nutrition in rice production systems: a review. Plant Soil, 361: 203226

Sharma, B.D., H. Arora, R. Kumar and V.K. Nayyar, 2004. Relationships between soil characteristics and total and DTPA-extractable micronutrients in inceptisols of Punjab. Comm. Soil Sci. Plant Anal., 35: 799-818

Smirnoff, N., 1993. The role of active oxygen in the response of plants to water deficit and desiccation. New Phytol., 125: 27-58

Stoyanova, Z. and S. Doncheva, 2002. The effect of zinc supply and succinate treatment on plant growth and mineral uptake in pea plant. Braz. J. Plant Physiol., 14: 111-116

Sun, S.Q., M. He, G. X. Wang and T. Cao, 2011. Heavy metal-induced physiological alterations and oxidative stress in the moss Brachythecium piligerum Chad. Environ. Toxicol., 26: 453-458

Tolrà, R.P., C. Poschenrieder and J. Barceló, 1996. Zinc hyperaccumulation in Thlaspi caerulescens. II. Influence on organic acids. J. Plant Nutr., 19: $1541-1550$

Wang, H. and J.Y. Jin, 2005. Photosynthetic rate, chlorophyll fluorescence parameters, and lipid peroxidation of maize leaves as affected by zinc deficiency. Photosynth., 43: 591-596

WHO, 2011. Micronutrient Deficiencies, Iron Deficiency Anemia

$\mathrm{Xu}$, W.H., H. Liu and Q.F. Ma, 2007. Effects of soil Zn levels on root exudates, rhizosphere $\mathrm{Zn}$ fractions and plant $\mathrm{Zn}$ accumulation of heavy metal enriching ryegrass. Pedosphere, 17: 389-396

$\mathrm{Xu}$, W.H., H. Huang and Z.T. Xiong, 2005. Effects of $\mathrm{Zn}$ on $\mathrm{Zn}$ accumulation and antioxidant enzymes activity in four varieties of ryegrass. Wuhan Univ. J. Nat. Sci., 10: 1051-1056

Yang, J.L., X.F. Zhu, C. Zheng, Y.J. Zhang and S.J. Zheng, 2011. Genotypic differences in $\mathrm{Al}$ resistance and the role of cell-wall pectin in A exclusion from the root apex in Fagopyrum tataricum. Ann. Bot., 107: $371-378$

(Received 20 October 2016; Accepted 30 December 2016) 